\title{
REPRYWATYZACJA A KONFLIKT INTERESÓW EKONOMICZNYCH JEDNOSTEK I PAŃSTWA - POLSKA NA TLE POZOSTAŁYCH KRAJÓW TRANSFORMACJ
}

\begin{abstract}
WSTĘP
Polska po 22 latach transformacji wciąż nie rozwiązała kwestii reprywatyzacji. Jak przyznaje sam rząd, „spośród krajów Europy Środkowo-Wschodniej jedynie Polsce nie udało się jeszcze uregulować prawnie istoty, zakresu i sposobu naprawienia krzywd, wyrządzonych aktami nacjonalizacyjnymi, wydanymi na skutek zmian politycznych, jakie zaszły po II wojnie światowej"1. W ciągu dwóch dekad powstało wiele projektów legislacyjnych, jednak żaden nie wszedł w życie. W dniu 9 marca 2011 rząd ogłosił, że prace nad projektem ustawy o świadczeniach pieniężnych przyznawanych niektórym osobom, których dotyczyty procesy nacjonalizacji zostały wstrzymane ${ }^{2}$. Oznacza to odsunięcie problemu zadośćuczynienia za zabrane mienie w nieokreśloną przyszłość. Postawa polskiego rządu i ustawodawcy wyraźnie kontrastuje $z$ działaniami podjętymi przez inne kraje regionu, które starały się przez reprywatyzację wyraźnie podkreślić zerwanie z poprzednim ustrojem i wprowadzić zasady konstytuujące nowy system społeczno-ekonomiczny, w którym państwo prawa stoi na straży własności prywatnej nie w sposób deklaratywny, ale i faktyczny. Jak wiadomo, budowę gospodarki socjalistycznej w Polsce, ale

1 Ministerstwo Skarbu Państwa, Projekt ustawy wraz z uzasadnieniem i ocenq skutków regulacji. (Wariant $z$ udziatem samorzqdu) $z d n$. 18.05.2009 r., http://bip.msp.gov.pl/portal/bip/103/3012/ Projekt_ustawy_o_swiadczeniach_pienieznych_przyznawanych_niektorym_osobom_ktoryc.html, (data dostępu: 4.06.2011).

2 Ministerstwo Skarbu Państwa, Informacja na temat prac nad projektem ustawy o świadczeniach pieniężnych przyznawanych niektórym osobom, których dotyczyty procesy nacjonalizacji, 9.03.2011, http://www.msp.gov.pl (data dostępu: 10.06.2011).
\end{abstract}


i w innych krajach byłego bloku wschodniego, oparto na szeregu aktów nacjonalizacyjnych, które w rażący sposób łamały prawo własności. Co więcej, wiele składników majątkowych zostało przejętych przez państwo z naruszeniem tych przepisów.

Proces przeniesienia własności z powrotem w ręce prywatne chyba najsprawniej przebiegł u naszych zachodnich sąsiadów. Przypisać to można niewątpliwie specyficznemu charakterowi niemieckiej transformacji - była NRD otrzymała gotowy zestaw instytucji, regulacji i olbrzymią pomoc materialną ze strony Republiki Federalnej. Pomimo wszelkich różnic pomiędzy Polską a byłą NRD i innymi krajami Europy Środowo-Wschodniej, warto porównać różne koncepcje reprywatyzacyjne, gdyż ogniskuje się w nich szereg ciekawych zależności - stosunku państwa do prawa własności, konsekwencji w działaniu ustawodawcy i rządu oraz zakresu dokonanej lub planowanej reprywatyzacji.

\section{REPRYWATYZACJA W PRAKTYCE POLSKIEJ}

Wprowadzenie socjalizmu oznaczało zburzenie fundamentu własności prywatnej, na którym opierała się gospodarka przedwojennej Polski. Przemiany po 1989 r. odwracają ten proces i prowadzą do odbudowy gospodarki rynkowej z przeważającą rolą sektora prywatnego. Wydaje się zatem truizmem twierdzenie, co podkreśla W. Łączkowski, że proces prywatyzacji powinien być poprzedzony uporządkowaniem stosunków własnościowych, między innymi przez reprywatyzację. Odwrócenie tej kolejności może okazać się i okazuje się zresztą w praktyce niebezpieczne, prowadząc do komplikacji prawnych, polegających na prywatyzowaniu majątku, którego własność jest niepewna ${ }^{3}$.

Konstytucja z 1997 r. tworzy wystarczające ramy prawne dla regulacji reprywatyzacji. Należą do nich: zasada państwa prawnego i sprawiedliwości społecznej, zasada zaufania obywateli do państwa, zasada równości oraz gwarancje własności. Wybór konkretnej formy i metody reprywatyzacji należy już do ustawodawcy zwykłego ${ }^{4}$. W szczególności artykuł 64 stanowi, że „Każdy ma prawo do własności, innych praw majątkowych oraz prawo dziedziczenia. Własność, inne prawa majątkowe oraz prawo dziedziczenia podlegają równej dla wszystkich ochronie

3 W. Łączkowski, Ustrojowe podstawy reprywatyzacji w III Rzeczypospolitej Polskiej, [w:] Reprywatyzacja w systemie prawa. Materiaty z konferencji zorganizowanej przez Komisje Ustawodawcza Senatu we wspótpracy z Ministerstwem Skarbu Państwa, Warszawa 1999, s. 27.

4 K. Dobrzeniecki, Reprywatyzacja-problem nadal nierozwiqzany, „Infos” 18.03.2010, Biuro Analiz Sejmowych. 
prawnej. Własność może być ograniczona tylko w drodze ustawy i tylko w zakresie, w jakim nie narusza ona istoty prawa własności”

U progu transformacji rozwiązano jedynie dwie kwestie związane ze zwrotem mienia przejętego przez państwo w okresie komunistycznym. Pierwsza regulacja dotyczyła restytucji majątku związków zawodowych, druga - Kościoła katolickiego i innych Kościołów i związków wyznaniowych. Trudno nie łączyć tego faktu ze szczególnym wkładem tych instytucji w doprowadzenie do zmiany ustrojowej oraz z ich wpływami politycznymi.

Ustawa z dnia 17 maja 1989 r. o stosunku państwa do Kościoła katolickiego w Rzeczypospolitej Polskiej ${ }^{6}$ określiła wzajemną sytuację prawną i majątkową. W Dziale IV: Przepisy przejsciowe i końcowe zawierała między innymi przepisy dotyczące tzw. postępowania regulacyjnego. Zgodnie $\mathrm{z}$ nimi postępowanie regulacyjne było wszczynane na wniosek kościelnych osób prawnych w przedmiocie przywrócenia im własności upaństwowionych nieruchomości lub ich części.

W toku zakończonych postępowań regulacyjnych Komisja Majątkowa przekazała kościelnym osobom prawnym nieruchomości o łącznym obszarze ponad 65,5 tys. hektarów oraz rekompensatę i odszkodowania w wysokości niemal $144 \mathrm{mln} \mathrm{zł}^{7}$. Trudno oszacować łączną wartość nieruchomości, ale przyjmując bardzo ostrożną - cenę $30 \mathrm{z} / \mathrm{m}^{2}$, wynosiłaby ona około $20 \mathrm{mld}$ zł.

Prace Komisji budziły szereg wątpliwości prawnych (np. brak możliwości odwołania od jej decyzji), a skutki jej działań wywoływały wiele społecznych emocji, zwłaszcza gdy naruszały interesy osób trzecich ${ }^{8}$ i wiązały się z komercyjnym obrotem otrzymaną ziemią. 8 czerwca 2011 r. Trybunał Konstytucyjny za niezgodny z Konstytucją uznał tylko jeden przepis, mówiący, że rząd określał w rozporządzeniu, a nie w ustawie, mienie których jednostek Skarbu Państwa lub samorządu Komisja może przekazać Kościołowi. Pozostałe sześć wniosków posłów SLD nie zostało uwzględnionych'

5 Konstytucja Rzeczypospolitej Polskiej z 2.04.1997 r.

6 Dz. U., nr 29, poz. 154, z późn. zm.

7 Komisja Majątkowa, Sprawozdanie z dziatalności Komisji Majątkowej w latach 1989-2011, 2.03.2011, http://bip.mswia.gov.pl/portal/bip/225/19415/Sprawozdanie_ktore_otrzymalo_Ministerstwo_Spraw_Wewnetrznych_i_Administracji_od_.html (data dostępu: 11.06.2011).

8 M. Bunda, Pozbawieni majątku przez Komisje Majątkowa, „Polityka” 16.03.2011.

9 Trybunal Konstytucyjny, Komunikat prasowy po rozprawie dotyczacej Komisji Majatkowej, http://www.trybunal.gov.pl/Rozprawy/2011/rozprawy.htm (data dostępu: 13.06.2011). 


\section{PRÓBY REGULACJI REPRYWATYZACJ W POLSCE}

Po 1989 r. powstało kilka projektów ustaw reprywatyzacyjnych, jednak żadna nie została uchwalona. Na przeszkodzie stały problemy natury finansowej, ale przede wszystkim politycznej. W 2001 r. Sejmowi udało się uchwalić ustawę reprywatyzacyjną, która - w zamyśle - miała rozwiązać problemy zwrotu majątku, jednak prezydent A. Kwaśniewski zawetował ją, argumentując, iż budżet nie jest w stanie jej sfinansować, oraz wskazując na zbyt mało - jego zdaniem - precyzyjne kryteria wyceny majątku. W związku z tym Ustawa z 7 marca 2001 r. o reprywatyzacji nieruchomości i niektórych ruchomości osób fizycznych przejętych przez państwo lub gminę miasta stołecznego Warszawy oraz o rekompensatach nie weszła w życie. W myśl tej ustawy wywłaszczone nieruchomości, o ile znajdowały się w zasobie Skarbu Państwa, miały zostać zwrócone. Drugą metodą reprywatyzacji miały stanowić bony reprywatyzacyjne o wartości 50\% wywłaszczonej nieruchomości.

W 2009 r. Ministerstwo Skarbu przygotowało kolejny projekt - Ustawę o świadczeniach pieniężnych przyznawanych niektórym osobom, których dotyczyły procesy nacjonalizacji. W uzasadnieniu do projektu napisano, że „przekształcenia własnościowe, jakie się dokonały po 1989 r., oraz konieczność zagwarantowania wszystkim uprawnionym równego traktowania nie pozwalają na przeprowadzenie reprywatyzacji opartej na zwrocie mienia w naturze bądź wypłacie pełnych odszkodowań. Jedyną formą może być publicznoprawne świadczenie pieniężne w wysokości niezagrażającej finansom publicznym”10. Projekt nie brał pod uwagę roszczeń z tytułu przejęcia przez państwo nieruchomości na podstawie dekretu z 26.10.1945 r. o własności i użytkowaniu gruntów na obszarze m.st. Warszawy, które powinny - wedle projektu - zostać rozwiązane odrębnymi przepisami. Celem projektu było jedynie „złagodzenie krzywd doznanych w toku decyzji nacjonalizacyjnych na podstawie wydanych w latach 1944-1962 dekretów PKWN i ustaw uchwalonych przez Sejm PRL obciążonych wadami, jak: przekroczenie granic nacjonalizacji, niewykonanie świadczeń i wady ustaw nacjonalizacyjnych".

Ustawa miała być realizowana $\mathrm{w}$ dwóch etapach. W pierwszym, trwającym 12 miesięcy, miały spływać wnioski, w kolejnym, sześciomiesięcznym, wojewodowie mieli podejmować decyzje o przyznaniu świadczenia. Wypłaty miały być wypłacane aż przez 15 lat, co wynikało z konieczności zgromadzenia środków finansowych, które przewidziano na $20 \mathrm{mld}$ zł. Źródłem finansowania wypłat miały być $\mathrm{m}$.in. środki pochodzące ze sprzedaży $5 \%$ akcji należących do Skarbu Państwa, przychody ze sprzedaży gruntów z zasobu Własności Rolnej Skarbu Państwa, wpływy ze sprzedaży lasów.

10 Ministerstwo Skarbu Państwa, Projekt... 
Można zatem odnieść wrażenie, że polski ustawodawca nie neguje samego procesu nacjonalizacji, uznaje w pełni ówczesne akty prawne i pragnie jedynie naprawić nieprawidłowości, które wystąpiły w trakcie wdrażania owych regulacji w życie. Gdyby zatem komunistyczne władze trzymały się wiernie litery stanowionego przez siebie prawa nacjonalizującego, omawiana ustawa nie byłaby w ogóle potrzebna. Ustawodawca nie zdecydował się bowiem na uznanie przepisów nacjonalizacyjnych za tzw. prawa rażąco niegodziwe. Gdyby uznał nieważność praw niegodziwych, wszelkie skutki prawne powstałe od początku ich obowiązywania zostałyby unicestwione, a sądy nie musiałyby dociekać, czy konfiskata mienia przebiegała w sposób zgodny, czy sprzeczny z obowiązującym wówczas owym prawem niegodziwym ${ }^{11}$. Projekt nie aspirował do całościowej regulacji problemów reprywatyzacji, czego dowodziła sama nazwa ustawy, w której termin „reprywatyzacja” zastąpiło najpierw „zadośćuczynienie”, zmienione zresztą w trakcie prac na „świadczenie pieniężne”.

Środowiska i organizacje byłych właścicieli nieruchomości z dużą rezerwą odniosły się do projektu, krytykując m.in. brak możliwości zwrotu mienia w naturze, co byłoby - ich zdaniem - nie tylko bardziej sprawiedliwe, ale i tańsze. Zwraca się uwagę, że wiele nieruchomości, będących w ręku państwa, niszczeje bez opieki ${ }^{12}$. Projekt uzyskał negatywną opinię Komisji Wspólnej Rządu i Samorządu Terytorialnego odnośnie do partycypacji samorządów w finansowaniu świadczeń przewidzianych ustawą. Podobnie minister finansów został zobowiązany do dokonania analizy dotyczącej wpływu wejścia w życie projektowanej regulacji na przyrost długu sektora finansów publicznych w perspektywie lat 2013-2016. Minister finansów 5 marca 2010 roku wskazał, iż w przypadku wejścia przedmiotowej ustawy w życie w 2012 r., z chwilą zakończenia wydawania decyzji administracyjnych dotyczących przyznania świadczeń nastąpi skokowy wzrost długu publicznego o 18 mld zł i relacji długu do PKB o ok. 1,0-1,1 punktu procentowego. Wedle Ministerstwa przeznaczenie na realizację ustawy kwoty 20 mld złotych może zatem spowodować przekroczenie przez Polskę dozwolonej przez Unię Europejską bariery długu publicznego w stosunku do PKB.

Jak ogłosiło Ministerstwo Skarbu, ,projekt ustawy o świadczeniach pieniężnych przyznawanych niektórym osobom, których dotyczyły procesy nacjonalizacji, jest więc przygotowany. Jednak ze względu na znaczące, czynione w ostatnich latach oszczędności, związane z globalnym kryzysem finansowym w wielu dziedzinach naszego życia społecznego i gospodarczego oraz duże obciążenia finansowe wynikające $z$ tej ustawy, w obecnej sytuacji ekonomicznej projekt ustawy nie

11 W. Eączkowski, op. cit.

12 Polskie Towarzystwo Ziemiańskie, Stanowisko PTZ w kwestii reprywatyzacji, http://www. ptz.info.pl (data dostępu: 13.06.2011). 
może być przeprowadzony" ${ }^{13}$. Decyzja ta odsuwa rozwiązanie problemu w nieokreśloną przyszłość.

\section{SKALA ROSZCZEŃ A FUNDUSZE NA REPRYWATYZACJĘ I ODSZKODOWANIA}

Skala potencjalnych roszczeń jest trudna do ustalenia. W 2008 r. oszacowano je na 140 mld zł. Na wartość tę składają się roszczenia dotyczące tzw. nieruchomości warszawskich w wysokości około $40 \mathrm{mld}$ zł oraz roszczenia dotyczące nieruchomości ziemskich, lasów, nieruchomości miejskich i przemysłowych, wynoszące 100 mld $\mathrm{zt}^{14}$. Powstaje pytanie, czy finanse państwa byłyby w stanie udźwignąć taki ciężar? Stanowiłoby to przecież około 11\% PKB (w roku 2008 w cenach bieżących) i ponad połowę wydatków budżetu. Nawet gdyby przeznaczono na ten cel wszystkie zasoby majątku państwowego w formie akcji i udziałów przedsiębiorstw, nie udałoby się uzyskać takiej kwoty. Nie ulega zatem wątpliwości, że sfinansowanie reprywatyzacji w formie spłaty pieniężnej, nawet rozłożonej na dłuższy okres, jest nierealne.

Zgodnie $\mathrm{z}$ art. 56 ust. 1 pkt 1 Ustawy z 30 sierpnia 1996 r. o komercjalizacji i prywatyzacji (Dz. U. z 2002 r., nr 171, poz. 1397) środki uzyskiwane ze sprzedaży 5\% akcji należących do Skarbu Państwa każdej ze spólek powstałych w wyniku komercjalizacji łącznie $\mathrm{z}$ odsetkami przeznacza się na cele związane z zaspokojeniem roszczeń byłych właścicieli mienia przejętego przez Skarb Państwa na podstawie dekretów i ustaw nacjonalizacyjnych oraz mienia przejętego w wyniku orzeczenia przepadku lub konfiskaty za działalność na rzecz niepodległego bytu państwa polskiego. Środki finansowe są gromadzone na rachunku państwowego funduszu celowego pod nazwą Fundusz Reprywatyzacji, którego dysponentem jest minister skarbu. Zgodnie z Ustawą z dnia 29 kwietnia 2010 r. o zmianie ustawy o komercjalizacji i prywatyzacji oraz Ustawy - Przepisy wprowadzające ustawę o finansach publicznych (Dz. U. z 2010 r., nr 108, poz. 685) wysokość odpisu na Fundusz Reprywatyzacji zmniejszono z 5\% do 1,5\% środków uzyskanych ze sprzedaży akcji/udziałów należących do Skarbu Państwa w każdej ze spółek powstałych w wyniku komercjalizacji. Zmniejszony odpis na Fundusz obowiązuje od dnia 3 lipca 2010 r. do 31 grudnia 2011 r. Dodatkowo, ze względu na trudną sytuację finansów publicznych, w 2011 r. Fundusz musiał przekazać na poczet przychodów budżetu państwa jednorazową wpłatę w wysokości 1 mld zł.

\footnotetext{
13 Ministerstwo Skarbu Państwa, Informacja...
}

14 Ministerstwo Skarbu Państwa, Projekt... 
Sytuacja finansowa Funduszu zaprezentowana jest w tabeli 1. Większość wydatków przeznaczana jest na cele statutowe. Jak zwraca uwagę U. Smołkowska, wysokie salda funduszu są wynikiem przewlekłości postępowań administracyjnych i sądowych oraz pochodną niezrealizowania w poprzednich latach planów wydatków na ustawowe cele ${ }^{15}$.

Tabela 1. Przychody, wydatki i stan Funduszu Reprywatyzacji w wybranych latach (w tys. zł)

\begin{tabular}{|c|c|c|c|c|}
\hline RoK & StAN NA POCZATEK ROKU & PrZYChODY & WydatKI & StAN NA KONIEC ROKU \\
\hline 2005 & 1662345 & 180000 & 521300 & 1321045 \\
\hline 2010 & 4896863 & 1180243 & 585345 & 5491734 \\
\hline 2011 & 4662523 & 173700 & 732700 & 4103523 \\
\hline
\end{tabular}

Źródło: Rządowe projekty ustaw budżetowych za dane lata, Sejm Rzeczypospolitej Polskiej, http://www. sejm.gov.pl (data dostępu: 11.06.2011).

Oparcie przychodów Funduszu na wpływach z prywatyzacji oznacza, że prognozowanie jego stanu finansowego obciąża znaczne ryzyko. Jak wiadomo, wpływy z prywatyzacji na ogół znacznie się różnią od projektów zapisanych w ustawach budżetowych i w dekadzie 2000-2010 kształtowały się przeciętnie na poziomie 3-10 mld zł.

Innym funduszem, który ma za zadanie obsługiwać roszczenia osób, które pozostawiły majątek poza obecnymi granicami Rzeczypospolitej Polskiej, jest Fundusz Rekompensacyjny, również pozostający w gestii Ministra Skarbu. Wedle projektu budżetu na 2011 r., początkowy stan Funduszu wynosił $879 \mathrm{mln}$ zł, na koniec roku zaś saldo ma wynieść $387 \mathrm{mln}$ zł. Według danych Ministerstwa Skarbu, od początku prowadzenia wypłat do końca maja 2011 r. Bank Gospodarstwa Krajowego wypłacił z Funduszu Rekompensacyjnego ogółem 37938 rekompensat na kwotę ponad $1668 \mathrm{mln} \mathrm{z}^{16}$.

Brak kompleksowej regulacji nie oznacza jednak, że państwo nie ponosi kosztów zaniechania. Wobec braku wspomnianych ustaw roszczenia dochodzone są na drodze sądowej. Jak zauważa sam rząd: „od wielu lat wydawane są orzeczenia sądowe oraz decyzje administracyjne, korzystne dla ubiegających się o zwrot nieruchomości lub odszkodowania na znaczne sumy, wynikające w wyliczanej stu-

15 U. Smołkowska, Opinia o projekcie budżetu państwa na rok 2011 w zakresie planów finansowych funduszy: Skarbu Państwa, Reprywatyzacji, Restrukturyzacji Przedsiębiorstw i Rekompensacyjnego, [w:] Biuro Analiz Sejmowych, Budżet Państwa na rok 2011, Ekspertyzy szczegótowe 2, Druk Sejmowy nr 3429, grudzień 2010 r.

16 Ministerstwo Skarbu, Komunikat nr 6/2011 w sprawie wyptat rekompensat z tytutu pozostawienia nieruchomości poza obecnymi granicami Rzeczypospolitej Polskiej, http://www.msp.gov.pl (data dostępu: 11.06.2011). 
procentowej wartości poniesionych szkód. Dalsze zatem utrzymywanie obecnego stanu stanowi obciążenie finansów publicznych, nie rozwiązując problemu w sposób globalny"17.

Ze ścieżki administracyjnej - wobec braku ustaw reprywatyzacyjnych - korzysta od połowy lat 90 . warszawski samorząd, który oddał w ten sposób około 2,5 tys. nieruchomości, jednak kilkanaście tysięcy wciąż czeka w kolejce. W stolicy obowiązywał tzw. dekret Bieruta, który przejmował prywatną własność, jednak w pewnych przypadkach byli właściciele mogli składać wnioski o przywrócenie własności, jednak mieli na to tylko pół roku. Takich wniosków złożono około 17 tysięcy. Właściciele kamienic nie mogli w przeciwieństwie do właścicieli domów otrzymać odszkodowania ani zwrotu ${ }^{18}$. Trybunał Konstytucyjny 13 czerwca 2011 r. uznał takie nierówne traktowanie właścicieli za niezgodne z konstytucją i zobowiązał Sejm do zmiany przepisów, otwierając drogę do odszkodowań wszystkim bez względu na wielkość nieruchomości ${ }^{19}$. Ciężar odszkodowań szacowano, wedle M. Bojko, dyrektora Biura Gospodarki Nieruchomościami, „kilka lat temu na 15 mld złotych", co przekracza stołeczny budżet o 2 mld złotych ${ }^{20}$.

Alternatywnym rozwiązaniem wobec wypłat pieniężnych mogłoby być podejście proponowane przez chociażby Polskie Towarzystwo Ziemiańskie, które stoi na stanowisku, że „Z zasobów Skarbu Państwa lub samorządów terytorialnych należy zwrócić prawowitym właścicielom lub ich spadkobiercom te majątki, które nie zostały rozparcelowane [...]. Tym osobom, których majątki rozparcelowano, należy zaproponować mienie zastępcze z zasobów Skarbu Państwa lub gmin. Pozostałym właścicielom lub spadkobiercom, którym z różnych przyczyn nie można oddać zabranego majątku, należy wypłacić odszkodowanie w gotówce lub papierach wartościowych, gwarantowanych przez Skarb Państwa, których realizacja mogłaby być rozłożona na raty" ${ }^{21}$. Zgodnie z intencją Towarzystwa takie rozwiązanie problemu powinno być wypracowane na zasadzie powszechnego konsensusu i pozwoliłoby uniknąć konieczności obciążania jego kosztami innych grup społecznych.

\footnotetext{
17 Ministerstwo Skarbu Państwa, Projekt...

18 I. Szpala, M. Zubik, Odszkodowania mogq kosztować Warszawę 15 mld ztotych, „Gazeta Wyborcza" 17.06.2011.

19 Trybunał Konstytucyjny, Komunikat prasowy po ogtoszeniu wyroku dotyczacego stosowania przepisów o odszkodowaniu za wywtaszczone nieruchomości, które na podstawie dekretu z 26 października 1945 roku o wtasności i użytkowaniu gruntów na obszarze m.st. Warszawy przeszty na wtasność państwa, http://www.trybunal.gov.pl/Rozprawy/2011/rozprawy.htm (data dostępu: 10.10.2011).

20 I. Szpala, M. Zubik, op. cit.

21 Polskie Towarzystwo Ziemiańskie, Stanowisko PTZ...
} 


\section{REPRYWATYZACJA W WYBRANYCH KRAJACH EUROPY ŚRODKOWO-WSCHODNIEJ}

Jak wcześniej wspomniano, Polska - dawny lider transformacji społeczno-ustrojowej, jest ostatnim państwem byłego bloku wschodniego, które nie przeprowadziło reprywatyzacji. Większość krajów Europy Środkowo-Wschodniej wprowadziła stosowne regulacje prawne na samym początku przemian - w latach 1990-1992. Umożliwiło to dokonanie zwrotu większości mienia osobom wywłaszczonym przed wprowadzeniem większych przemian własnościowych, np. w drodze prywatyzacji czy komunalizacji.

Jednym z pierwszych krajów, który unormował zasady zwrotu znacjonalizowanego majątku dawnym właścicielom, była NRD. Regulacja spraw własnościowych była jednym $z$ najważniejszych tematów negocjacyjnych pomiędzy dwoma jednoczącymi się państwami niemieckimi ${ }^{22}$. Zagadnienie to uznano za na tyle istotne, iż poświęcono mu odrębny dokument - Wspólną Deklarację ${ }^{23}$ włączoną następnie do Traktatu Zjednoczeniowego ${ }^{24}$.

Najważniejszy akt prawny w zakresie reprywatyzacji został wydany jeszcze przez władze NRD. Była to ustawa o uregulowaniu niewyjaśnionych spraw majątkowych z 23 września 1990 r. - Vermögensgesetz (dalej: ustawa majątkowa) ${ }^{25}$. Ustawa wprowadzała naczelną zasadę restytucji majątków na rzecz poprzednich właścicieli lub ich spadkobierców. Zasada ta zresztą została już przyjęta we Wspólnej Deklaracji. Ustawa majątkowa była wielokrotnie nowelizowana. Problematyce reprywatyzacji poświęcono także szereg innych aktów prawnych, często zmieniających pierwotne reguły ustalone w ustawie majątkowej.

Specyfika niemieckich przemian polegała przede wszystkim na szerokim zakresie reprywatyzacji - zarówno podmiotowym, jak i przedmiotowym. Każdemu, kogo pozbawiono majątku, bez względu na narodowość, obywatelstwo, rasę, religię, przekonania polityczne, przyznano prawo do zwrotu majątku lub odszkodo-

22 Zob. A. Falkowska, Restytucja, odszkodowanie czy inwestycje? - reprywatyzacja majątku Niemieckiej Republiki Demokratycznej, „Ekonomia i Prawo” 2011, t. VII, cz. I, s. 270.

23 Wspólna Deklaracja Rządów RFN i NRD w sprawie uregulowania niewyjaśnionych spraw majątkowych z 15 czerwca 1990 r. (Gemeinsame Erklärung der Regierungen der Bundesrepublik Deutschland und der Deutschen Demokratischen Republik zur Regelung offener Vermögensfragen, 15. Juni 1990, BGB1. 1990 II, S. 1237-38).

24 Art. 41 (1) Traktatu pomiędzy RFN i NRD w sprawie przywrócenia jedności Niemiec Traktat Zjednoczeniowy (Vertrag zwischen der Bundesrepublik Deutschland und der Deutschen Demokratischen Republik über die Herstellung der Einheit Deutschlands (Einigungsvertrag), 31. August 1990, BGB1. 1990 II, S. 903).

25 Gesetz zur Regelung offener Vermögensfragen (VermG), 23. September 1990, BGB1 1990 II, S. 885 . 
wania ${ }^{26}$. Przepisy niemieckie nie przewidywały też ograniczeń co do przedmiotu roszczeń reprywatyzacyjnych - uprawnieni mogli starać się o zwrot lub rekompensatę za utracone nieruchomości (rolne, budynkowe, lokalowe), przedsiębiorstwa, wszelkiego rodzaju ruchomości, w tym dzieła sztuki, papiery wartościowe, prawa na dobrach niematerialnych ${ }^{27}$. Żadne $\mathrm{z}$ państw postkomunistycznych nie przeprowadziło reprywatyzacji tak różnorodnych kategorii mienia.

Przewidziano jednak jedno poważne ograniczenie - już we Wspólnej Deklaracji, a następnie w ustawie majątkowej ustalono, iż zwrotowi nie będą podlegać majątki wywłaszczone w okresie istnienia radzieckiej strefy okupacyjnej, tj. w latach 1945-194928. Same skonfiskowane wówczas nieruchomości stanowiły około 1/3 powierzchni byłej NRD. Dla poprzednich właścicieli tego mienia nie przewidziano również żadnego odszkodowania. Kontrowersyjna regulacja stała się przedmiotem równie dyskusyjnego rozstrzygnięcia Federalnego Trybunału Konstytucyjnego. W wyroku z 23 kwietnia 1991 r. utrzymał on w mocy postanowienia Traktatu Zjednoczeniowego, sankcjonując tym samym nieodwracalność wywłaszczeń z okresu 1945-1949. Odmiennie od ustawodawcy, Trybunał przyjął jednak, iż byłym właścicielom należy się pewne odszkodowanie. Na realizację tego postulatu poszkodowani musieli czekać jeszcze 3 lata - w 1994 r. uchwalono ustawę o świadczeniach wyrównawczych za mienie wywłaszczone na podstawie przepisów okupacyjnych ${ }^{29}$.

Należy podkreślić, iż niemiecki ustawodawca, regulując problematykę nierozwiązanych spraw majątkowych, miał do rozstrzygnięcia bardzo złożony problem. Poza wspomnianym już okresem wywłaszczeń władz okupacyjnych, konfiskaty mienia nastąpiły już wcześniej - w latach 1933-1939 w okresie reżimu nazistowskiego. Odmiennie od wcześniej analizowanej sytuacji, przepisy reprywatyzacyjne

26 M. Granat, Problem reprywatyzacji w wybranych państwach Europy Środkowej i Wschodniej, [w:] Reprywatyzacja w systemie prawa. Materiaty z konferencji zorganizowanej przez Komisje Ustawodawcza Senatu we wspótpracy z Ministerstwem Skarbu Państwa, Warszawa 1999, s. 107. Por. także art. 1 VermG.

27 M. Tkaczyk, Prawne regulacje reprywatyzacji w wybranych krajach Europy Środkowowschodniej, „Myśl Ekonomiczna i Prawna” 2005, nr 4, s. 58-59.

28 Władze NRD sprzeciwiały się szczególnie silnie reprywatyzacji tych majątków, podnosząc jednocześnie, iż pełną odpowiedzialność za wywłaszczenia z lat 1945-1949 ponoszą władze radzieckie. Według uproszczonych rachunków zaspokojenie roszczeń w tym zakresie kosztowałoby około 8 miliardów marek, czego nie udźwignąłby budżet NRD (W. Schäuble, Der Vertrag. Wie ich über die deutsche Einheit verhandelte, Stuttgart 1991, s. 259-261). Przypuszcza się także, iż utrzymanie w mocy zmian dokonanych w drodze reformy rolnej przeprowadzonej w radzieckiej strefie okupacyjnej było jednym z warunków wyrażenia przez ZSRR zgody na zjednoczenie Niemiec. M. Gorbaczow w 1994 r. oficjalnie zaprzeczył tym przypuszczeniom (M. Tkaczyk, op. cit., s. 58).

29 Gesetz über staatliche Ausgleichsleistungen für Enteignungen auf besatzungsrechtlicher oder besatzungshoheitlicher Grundlage, die nicht mehr rückgängig gemacht werden können (Ausgleichsleistungsgesetz-AusglLeistG) BGB1. 1994 I, S. 2628. 
wyraźnie objęły ofiary konfiskat nazistowskich, przewidując dla nich zwrot mienia lub odszkodowanie.

Podstawową formą reprywatyzacji przyjętą w Niemczech była restytucja - zwrot majątku prawowitym właścicielom. Jak wcześniej wspomniano, zasadę pierwszeństwa restytucji przewidywała wyraźnie Wspólna Deklaracja oraz ustawa majątkowa. Oba akty zawierały jednocześnie szereg wyjątków od reguły zwrotu majątku w naturze. W szczególności restytucja była niedopuszczalna, gdy istotnie zmieniono przeznaczenie lub sposób użytkowania mienia, które następnie zostało wykorzystane na cele publiczne albo zostało nabyte przez osoby trzecie w dobrej wierze. W takim wypadku były właściciel mógł uzyskać jedynie odszkodowanie pieniężne. Kolejne akty prawne wprowadzały dalej idące wyjątki od zasady restytucji. Najważniejsze $z$ nich zawarto w prawie o szczególnych inwestycjach z 1990 r. ${ }^{30}$ Kierując się dobrem gospodarki, postanowiono, iż majątki, względem których zgłoszono roszczenia reprywatyzacyjne, mogą zostać sprzedane inwestorom, o ile istnieje wobec nich szczególny cel inwestycyjny. Przyjęte rozwiązania prawne nie pobudziły jednak w wystarczającym stopniu inwestycji $\mathrm{w}$ zrujnowanych ekonomicznie landach wschodnich. Długotrwałe, żmudne procedury oraz restrykcyjność przepisów spowodowały zamrożenie większości działań inwestorskich na terenie byłej NRD. Rząd i parlament niemiecki zareagowały jednak bardzo szybko - wiosną 1991 r., po zaledwie 4 miesiącach prac, uchwalono nowe regulacje usprawniające proces inwestycyjny ${ }^{31}$. Gdy zmiany okazały się niewystarczające, parlament niezwłocznie uchwalił prawo o pierwszeństwie inwestycji ${ }^{32}$. Regulacja, jak wynika $\mathrm{z}$ samej nazwy, oznaczała całkowitą zmianę priorytetów reprywatyzacyjnych, w miejsce restytucji wprowadzając odszkodowanie za wywłaszczony majątek. Pozwoliło to jednak na pobudzenie aktywności gospodarczej i zażegnanie problemów wynikających z niepewności prawnej co do większości majątków.

Równie szybko problematykę reprywatyzacji podjęto w Czechosłowacji. Jeszcze w okresie istnienia wspólnej państwowości uregulowanie zwrotu mienia przejętego przez państwo okazało się sprawą wymagającą pilnego uregulowania. Wynikało to z jednego z pierwszych aktów przyjętych po upadku reżimu socjalistycznego - ustawy o rehabilitacjach sądowych ${ }^{33}$. Na mocy tego aktu, ujmując to

30 Gesetz über besondere Investitionen in der Deutschen Demokratischen Republik, Gesetzblatt der Deutschen Demokratischen Republik, 27. September 1994, BGB1. 1990 I, S. 1897.

31 Było to prawo o usunięciu barier prywatyzacji przedsiębiorstw i wspieraniu inwestycji (Das Gesetz zur Beseitigung von Hemmnissen bei der Privatisierung von Unternebmen und zur Förderung von Investitionen z 22. März 1991 r., BGB1. 1991 I, S. 766).

32 Gesetz über den Vorrang für Investitionen bei Rückübertragungsansprüchen nach dem Vermögensgesetz (Investitionsvorranggesetz - InVorG) 14. Juli 1992, BGB1. I, S. 1268.

33 Ustawę uchwalono w maju $1990 \mathrm{r}$. 
w pewnym uproszczeniu, zniesione zostały wyroki sądowe wydane w poprzednim ustroju, w sprawach o przestępstwa przeciwko państwu ${ }^{34}$. Był to akt szczególny, jego wyjątkowość wyrażała się w uchyleniu ex lege dziesiątków tysięcy wyroków sądowych w sprawach karnych bez wznawiania tych postępowań ${ }^{35}$. Taki stan spowodował otwarcie problemu zwrotu majątku przejętego przez państwo na podstawie orzeczonej, w wyżej wymienionych sprawach, kary przepadku mienia. Jednocześnie rozgorzała dyskusja na temat zakresu podmiotowego, przedmiotowego i czasowego przyszłej reprywatyzacji. Chronologicznie pierwszą ustawą reprywatyzacyjną była uchwalona jeszcze w 1990 r. ustawa o uregulowaniu stosunków własności zakonów i kongregacji religijnych. $\mathrm{Na}$ jej podstawie zwrócono znaczną część przejętych przez państwo nieruchomości. Na marginesie należy wspomnieć, że reprywatyzacja majątku Kościoła rzymskokatolickiego ograniczona została w zasadzie do zwrotu jedynie budynków kościelnych ${ }^{36}$. Poza enumeratywnie wymienionymi nieruchomościami, nie przewidziano zwrotu innego mienia, w szczególności rozległych nieruchomości rolnych i leśnych ${ }^{37}$.

Również w 1990 r. przyjęto ustawę o łagodzeniu następstw niektórych krzywd majątkowych. Ustawa ta dotyczyła jedynie niektórych nieruchomości znacjonalizowanych w drodze kilku aktów prawnych (głównie rozporządzeń rządowych) wydanych po 1955 r. Ze względu na tak wąski zakres przedmiotowy i czasowy zaczęto ją nazywać małą ustawą reprywatyzacyjną. Przewidywała ona zwrot odebranego mienia lub przyznanie rekompensaty pieniężnej, równej cenie, za jaką nieruchomość została sprzedana innej osobie fizycznej.

$\mathrm{Na}$ początku 1991 r. przyjęto tzw. dużą ustawę reprywatyzacyjną ${ }^{38}$ - podstawowy akt prawny nie tylko w zakresie zwrotu znacjonalizowanego mienia, ale też naprawienia krzywd niemajątkowych. Ramy czasowe rehabilitacji pozasądowej zostały ściśle określone - ustawa obejmowała naprawienie szkód i zadośćuczynienie krzywdom wyrządzonym w okresie od 25.02.1948 r. do 31.12.1989 r. Wąsko ujęto również zakres podmiotowy ustawy - status osoby uprawnionej przysługiwał jedynie osobom posiadającym czechosłowackie obywatelstwo oraz stałe miej-

34 P. Rychetský, Prawne problemy reprywatyzacji w Republice Czeskiej, [w:] Reprywatyzacja w systemie prawa. Materiaty z konferencji zorganizowanej przez Komisje Ustawodawczq Senatu we wspótpracy z Ministerstwem Skarbu Państwa, Warszawa 1999, s. 137.

Ibidem.

36 P. Rychetský uzasadnił taką regulację „specyficznymi czeskimi doświadczeniami historycznymi i znacznymi rozbieżnościami politycznymi” (por. P. Rychetský, op. cit., s. 138).

37 M. Granat, op. cit., s. 107.

38 Ustawa z dnia 21.02.1991 r. o restytucji własności prywatnej w drodze pozasądowej (zwana też ustawą o rehabilitacjach pozasądowych). Zarówno w Czechach, jak i na Słowacji uchwalono jeszcze szereg innych aktów prawnych bezpośrednio lub pośrednio związanych z tematyką reprywatyzacyjną (zob. więcej: J. Kuklík, Restytucja dóbr w prawie czeskim i czechostowackim w latach 1989-2000, [w:] Dobra kultury i problemy wtasności: doświadczenia Europy Środkowej po 1989 r., Warszawa 2005, s. 31-37; M. Tkaczyk, op. cit., s. 63-70. 
sce pobytu na terenie Czechosłowacji. Takie rozwiązanie wywołało ostre protesty zwłaszcza ze strony Niemców sudeckich oraz emigracji żydowskiej. Po rozpadzie Czechosłowacji kryterium stałego pobytu zostało zaskarżone do Trybunału Konstytucyjnego zarówno Czech, jak i Słowacji. Czeski Trybunał Konstytucyjny uwzględnił skargę, co spowodowało usunięcie $\mathrm{z}$ ustawy wspomnianego warunku. Otworzyło to drogę emigrantom do występowania o zwrot majątku pozostawionego przez nich w kraju. Trybunał, pomijając ramy czasowe dużej ustawy reprywatyzacyjnej, umożliwił także występowanie Niemcom sudeckim o rekompensatę za majątek utracony przez nich w $1945 \mathrm{r}^{39}$

Odmienną decyzję podjął słowacki Trybunał Konstytucyjny, uznając kryterium stałego pobytu na terenie kraju za zgodne $z$ konstytucją. Rozstrzygnięcie dużej ustawy reprywatyzacyjnej zaskarżono więc do Europejskiego Trybunału Praw Człowieka w Strasburgu, ale również bez powodzenia - skarga została odrzucona ${ }^{40}$. Dopiero w 2000 r. rząd słowacki podjął decyzję o zwrocie majątku skonfiskowanego ofiarom Holocaustu w latach 1939-1945 ${ }^{41}$.

Zagadnienie reprywatyzacji majątku w byłej NRD, Czechach i Słowacji zrodziło wiele problemów prawnych. Jeszcze wiele lat po transformacji ustrojowej toczyły się postępowania sądowe związane ze zwrotem znacjonalizowanego mienia lub stosowną rekompensatą pieniężną. Te trudności były jednak nieuniknione w tak złożonym procesie, budzącym szereg wątpliwości prawnych, moralnych, społecznych oraz problemów ekonomicznych ${ }^{42}$. W literaturze wskazuje się jednak, iż samo przeprowadzenie reprywatyzacji we wskazanych krajach zakończyło się sukcesem ${ }^{43}$, który był możliwy dzięki szybkiemu uchwaleniu ustaw denacjonalizacyjnych. Stosowne działania podjęto natychmiast po upadku reżimu socjalistycznego, zanim majątek został w większości sprywatyzowany i przeniesiony na osoby trzecie. Oprócz wyżej wspomnianych krajów reprywatyzację przeprowadzono także m.in. na Węgrzech, w Bułgarii, Rumunii, Litwie, Łotwie, Estonii, Macedonii, Słowenii.

\footnotetext{
39 M. Tkaczyk, op. cit., s. 65.

40 P. Rychetský, op. cit., s. 139.

41 A. Niewiadomski, Rząd zwróci majątek Żydom, „Rzeczpospolita” 6.04.2000.

42 Według P. Makarca przeprowadzenie reprywatyzacji w Czechach kosztowało 40 mld dolarów (P. Makarzec, Reprywatyzacja w Polsce i w innych pañstwach Europy Środkowo-Wschodniej, „Studia Iuridica Lublinensia” 2003, t. 2, s. 101).

43 P. Makarzec, Różne modele reprywatyzacji w Europie Środkowo-Wschodniej na przyktadzie Czech, Niemiec i Wegier, „Studia Iuridica Lublinensia” 2006, t. 7, s. 156; idem, Reprywatyzacja w Polsce..., s. 102.
} 


\section{ZAKOŃCZENIE}

Trudno nie zgodzić się z poglądem A. Herbeta, że „historyczne, ekonomiczne, prawne i moralne reperkusje procesów nacjonalizacji i reprywatyzacji stanowią tło jednego z najpoważniejszych problemów legislacji okresu transformacji”"44. Nie wydaje się jednak, by mogło to stanowić wystarczające wytłumaczenie dla braku rozwiązania kwestii reprywatyzacji w kraju, który był przecież inicjatorem przemian ustrojowych. Jak pokazują przykłady pozostałych krajów byłego bloku wschodniego, problem ten można było rozwiązać. Niewątpliwie wraz z upływem czasu szanse na wejście w życie jakiejkolwiek regulacji w tej materii maleją. Argumenty dotyczące finansów państwa są jak najbardziej racjonalne, ale nie do końca przekonują. Reprywatyzacja nie musi być przecież przeprowadzona w formie wypłat obciążających budżet. Przez dwie dekady przekształceń własnościowych nie zgromadzono środków, które mogłyby, choć na minimalnym poziomie, akceptowanym przez środowiska zainteresowane procesem zwrotu mienia, zabezpieczyć ich roszczenia ${ }^{45} . Z$ jednej strony, rząd deklaruje chęć zmierzenia się z tym wyzwaniem i nie kwestionuje konieczności naprawienia krzywd, z drugiej jednak - wykorzystuje każdą okazję, aby odsunąć problem.

Organizacje zwarte, sprawne i o znacznych wpływach politycznych potrafiły przeforsować korzystne dla siebie rozwiązanie kwestii zwrotu majątku. Pojedyncze osoby - byli właściciele lub ich spadkobiercy oraz tworzone przez nich organizacje i stowarzyszenia nie stanowią odpowiedniej grupy nacisku ani siły politycznej, z którą należy się liczyć. Dlatego też pozostaje im - jak na razie żmudna droga postępowania administracyjnego i sądowego w każdym indywidualnym przypadku.

Brak poczucia sprawiedliwości nie pomaga $\mathrm{w}$ integracji społecznej i rodzi konflikty na linii jednostka-państwo. W tym konflikcie jednostka wciąż stoi na słabszej pozycji.

Spory prawne rzutują wciąż na efektywność wykorzystania majątku w naszym kraju. Zgodnie z hipotezą H. de Soto, w wielu przypadkach kapitał pozostaje „martwy”- byli właściciele nie mogą bowiem go „ożywić”, a aktualni posiadacze boją się inwestować w składniki majątku, co do których wysuwane są roszczenia o zwrot, lub o nieuregulowanym stanie prawnym. Trudno wyobrazić sobie zakończenie przebudowy stosunków własnościowych bez rozwiązania kwestii reprywatyzacyjnych.

44 A. Herbet, Projekt stanowiska Sejmu w sprawie skargi konstytucyjnej (sygn. akt SK 26 109), dotyczacej ustawy z dnia 17 czerwca 2004 r. o zmianie ustawy - Kodeks cywilny oraz niektórych innych ustaw, „Zeszyty Prawnicze” 2009, nr 3-4 (23-24), s. 251.

${ }^{45}$ Część środowisk byłaby skłonna zaakceptować poziom 20\% roszczeń. Przyjmując ich wartość na 140 mld zł, oznaczałoby to konieczność zgromadzenia około 28 mld zł. 


\section{BIBLIOGRAFIA}

Bunda M., Pozbawieni majątku przez Komisje Majątkowa, „Polityka” 16.03.2011.

Dobrzeniecki K., Reprywatyzacja-problem nadal nierozwiqzany, „Infos”18.03.2010, Biuro Analiz Sejmowych.

Falkowska A., Restytucja, odszkodowanie czy inwestycje? - reprywatyzacja majątku Niemieckiej Republiki Demokratycznej, „Ekonomia i Prawo” 2011, t. VII, cz. I.

Granat M., Problem reprywatyzacji w wybranych państwach Europy Srodkowej i Wschodniej, [w:] Reprywatyzacja w systemie prawa. Materiaty z konferencji zorganizowanej przez Komisję Ustawodawczq Senatu we wspótpracy z Ministerstwem Skarbu Państwa, Warszawa 1999.

Herbet A., Projekt stanowiska Sejmu w sprawie skargi konstytucyjnej (sygn. akt SK 26/09), dotyczacej ustawy z dnia 17 czerwca 2004 r. o zmianie ustawy - Kodeks cywilny oraz niektórych innych ustaw, „Zeszyty Prawnicze” 2009, nr 3-4 (23-24).

Kuklík J., Restytucja dóbr w prawie czeskim i czechostowackim w latach 1989-2000, [w:] Dobra kultury i problemy wtasności: doświadczenia Europy Środkowej po 1989 r. Warszawa 2005.

Eączkowski W., Ustrojowe podstawy reprywatyzacji w III Rzeczypospolitej Polskiej, [w:] Reprywatyzacja w systemie prawa. Materiaty z konferencji zorganizowanej przez Komisję Ustawodawczq Senatu we wspótpracy z Ministerstwem Skarbu Państwa, Warszawa 1999.

Niewiadomski A., Rzq̨d zwróci majątek Żydom, „Rzeczpospolita” 6.04.2000.

Makarzec P., Reprywatyzacja w Polsce i w innych państwach Europy Środkowo-Wschodniej, „Studia Iuridica Lublinensia” 2003, t. II.

Makarzec P., Różne modele reprywatyzacji w Europie Środkowo-Wschodniej na przyktadzie Czech, Niemiec i Wegier, „Studia Iuridica Lublinensia” 2006, t. VII.

Rychetský P., Prawne problemy reprywatyzacji w Republice Czeskiej, [w:] Reprywatyzacja w systemie prawa. Materiaty z konferencji zorganizowanej przez Komisje Ustawodawcza Senatu we wspótpracy z Ministerstwem Skarbu Państwa, Warszawa 1999.

Schäuble W., Der Vertrag. Wie ich über die deutsche Einheit verhandelte, Stuttgart 1991.

Smołkowska U., Opinia o projekcie budżetu państwa na rok 2011 w zakresie planów finansowych funduszy: Skarbu Państwa, Reprywatyzacji, Restrukturyzacji Przedsiębiorstw i Rekompensacyjnego, [w:] Biuro Analiz Sejmowych, Budżet Państwa na rok 2011, Ekspertyzy szczegótowe 2, Druk Sejmowy nr 3429, grudzień 2010 r.

Szpala I., Zubik M., Odszkodowania mogq kosztować Warszawe 15 mld ztotych, „Gazeta Wyborcza”17.06.2011.

Tkaczyk M., Prawne regulacje reprywatyzacji w wybranych krajach Europy Środkowowschodniej, „Myśl Ekonomiczna i Prawna” 2005, nr 4. 


\section{AKTY PRAWNE}

Gesetz über besondere Investitionen in der Deutschen Demokratischen Republik, Gesetzblatt der Deutschen Demokratischen Republik, 23. September 1990, BGB1. 1990 I, S. 1897.

Gesetz über staatliche Ausgleichsleistungen für Enteignungen auf besatzungsrechtlicher oder besatzungshoheitlicher Grundlage, die nicht mebr rückgängig gemacht werden können (Ausgleichsleistungsgesetz - AusglLeistG) 27. September 1994, BGB1. 1994 I, S. 2628.

Gesetz über den Vorrang für Investitionen bei Rückübertragungsansprüchen nach dem Vermögensgesetz (Investitionsvorranggesetz - InVorG), 14. Juli 1992, BGB1. I, S. 1268.

Das Gesetz zur Beseitigung von Hemmnissen bei der Privatisierung von Unternehmen und zur Förderung von Investitionen, 22. März 1991, BGB1. 1991 I, S. 766.

Gesetz zur Regelung offener Vermögensfragen (VermG), 23. September 1990, BGB1 1990 II, S. 885 .

Konstytucja Rzeczypospolitej Polskiej z 2.04.1997 r. (Dz. U. nr 78, poz. 483).

Traktat pomiędzy RFN i NRD w sprawie przywrócenia jedności Niemiec-Traktat Zjednoczeniowy (Vertrag zwischen der Bundesrepublik Deutschland und der Deutschen Demokratischen Republik über die Herstellung der Einheit Deutschlands (Einigungsvertrag), 31. August 1990, BGB1. 1990 II, S. 903).

Ustawa z dnia 17 maja 1989 r. o stosunku państwa do Kościoła katolickiego w Rzeczypospolitej Polskiej (Dz. U. nr 29, poz. 154, z późn. zm.).

Wspólna Deklaracja Rządów RFN i NRD w sprawie uregulowania niewyjaśnionych spraw majątkowych z 15 czerwca 1990 r. (Gemeinsame Erklärung der Regierungen der Bundesrepublik Deutschland und der Deutschen Demokratischen Republik zur Regelung offener Vermögensfragen, 15. Juni 1990, BGB1. 1990 II, S. 1237-38).

\section{POZOSTAŁE ŹRÓDŁA}

Komisja Majątkowa, Sprawozdanie z dziatalności Komisji Majątkowej w latach 1989-2011, 2.03.2011, http://bip.mswia.gov.pl/portal/bip/225/19415/Sprawozdanie_ ktore_otrzymalo_Ministerstwo_Spraw_Wewnetrznych_i_Administracji_od_.html (data dostępu: 11.06.2011).

Ministerstwo Skarbu Państwa, Informacja na temat prac nad projektem ustawy o swiadczeniach pieniężnych przyznawanych niektórym osobom, których dotyczyty procesy nacjonalizacji, 9.03.2011, http://www.msp.gov.pl (data dostępu: 10.06.2011).

Ministerstwo Skarbu, Komunikat nr 6/2011 w sprawie wyptat rekompensat z tytutu pozostawienia nieruchomości poza obecnymi granicami Rzeczypospolitej Polskiej, http://www. msp.gov.pl (data dostępu: 11.06.2011).

Ministerstwo Skarbu Państwa, Projekt ustawy wraz z uzasadnieniem i ocenq skutków regulacji. (Wariant z udziatem samorzqdu) z dn. 18.05.2009, http://bip.msp.gov.pl/portal/ bip/103/3012/Projekt_ustawy_o_swiadczeniach_pienieznych_przyznawanych_niektorym_osobom_ktoryc.html (data dostępu: 4.06.2011). 
Polskie Towarzystwo Ziemiańskie, Stanowisko PTZ w kwestii reprywatyzacji, http://www. ptz.info.pl (data dostępu: 13.06.2011).

Trybunał Konstytucyjny, Komunikat prasowy po rozprawie dotyczqcej Komisji Majątkowej, http:/www.trybunal.gov.p1/Rozprawy/2011/rozprawy.htm (data dostępu: 13.06.2011).

Trybunał Konstytucyjny, Komunikat prasowy po ogtoszeniu wyroku dotyczacego stosowania przepisów o odszkodowaniu za wywtaszczone nieruchomości, które na podstawie dekretu z 26 października 1945 roku o wtasności i użytkowaniu gruntów na obszarze m.st. Warszawy przeszty na wtasnośćpaństwa, http://www.trybunal.gov.p1/Rozprawy/2011/ rozprawy.htm (data dostępu: 10.10.2011).

\title{
STRESZCZENIE
}

Cel opracowania stanowi porównanie polityki reprywatyzacyjnej prowadzonej w Polsce i w innych krajach Europy Środkowo-Wschodniej, ze szczególnym uwzględnieniem byłej NRD. W Polsce zaobserwować można zupełnie odmienne podejście do tej problematyki niż u naszych zachodnich sąsiadów. Pomimo że roszczenia dawnych właścicieli dotyczyły niemal 2/3 terytorium byłej NRD, niemiecki ustawodawca szybko i zdecydowanie rozwiązał te kwestie, dzięki czemu nie rzutują one na obecne życie społeczne i gospodarcze RFN. Polska natomiast po dwóch dekadach transformacji wciąż nie wypracowała jasnego stanowiska w tej sprawie, kolejne rządy zaś podejmują bezskuteczne próby regulacji lub odsuwają problem w bliżej nieokreśloną przyszłość. Taka praktyka każe wątpić, czy można uznać nasz kraj za w pełni zintegrowany z Zachodem, w sensie spełniania standardów nowoczesnego państwa, które rozwiązuje drażliwe sprawy i stara się likwidować punkty zapalne w kontaktach z zagranicą (np. zwrot mienia pożydowskiego).

Reprywatyzacja jest istotna $\mathrm{z}$ kilku przynajmniej powodów o naturze zarówno prawnej, jak i ekonomicznej. Brak rozwiązania dawnych krzywd rodzi poczucie niesprawiedliwości, generuje liczne konflikty na linii obywatel-państwo i rodzi wątpliwości co do gwarantowanej konstytucyjnie ochrony praw własności w naszym kraju. Z drugiej strony należy pytać o aspekty ekonomiczne ewentualnego programu odszkodowawczego - czy Polskę po prostu na to stać? Jakie są koszty zaniechania jakichkolwiek działań?

W pierwszej części opracowania omówiono uwarunkowania prawne i ekonomiczne procesu reprywatyzacji w Polsce, w drugiej zaś przybliżono regulacje dotyczące zwrotu majątku w wybranych krajach byłego bloku wschodniego.

\section{REPRIVATIZATION AND THE CONFLICT OF ECONOMIC INTERESTS OF INDIVIDUALS AND THE STATE - POLAND COMPARED TO OTHER COUNTRIES IN TRANSITION}

\author{
SUMMARY
}

The aim of the study is a comparison of re-privatization policy pursued in Poland and other countries of Central and Eastern Europe, with particular emphasis on the former 
GDR. Poland has chosen a completely different approach to this issue from that of the Germans. Despite the claims of former owners concerned, in almost 2/3 of the former GDR territory, the German legislature quickly and decisively resolved these issues, so that they do not impinge on the current social and economic life of Germany. Poland however, after two decades of transformation, has still not developed a clear position on this issue, while successive legislation projects end in failure or are postponed indefinitely. This practice leads to doubt as to whether our country can be regarded as fully integrated with the West in terms of compliance with standards of the modern state, which resolves sensitive issues and seeks to eliminate hot spots in contacts with foreign countries (e.g. the return of former Jewish property).

Reprivatization is important for several reasons, of both legal and economic nature. Lack of a solution raises a sense of injustice among former owners, generates numerous conflicts on the citizen-state line, and calls into question the constitutionally guaranteed protection of property rights in Poland. On the other hand, a thankless objective of an economist is to assess the economic aspects of a possible compensation program - could Poland afford it? What would be the costs of abandonment of any action?

In the first part of the study the regulations on property restitution in the former Eastern bloc countries are shortly discussed. Then attention is paid to the legal and economic conditions of the property restitution process in Poland. 